\title{
EFFECT OF ANGIOSPERMIC EPIPHYTES ON THE RELATIVE STATUS OF ERGOSTEROL AND ELECTROLYTE LEAKAGE IN FUNGAL PATHOGENS
}

\author{
HAMZAH JUMAH ESSA BARKAH, S. LOKESH* \\ Department of Studies in Biotechnology, University of Mysore, Manasagongatri, Mysuru 57006, Karnataka, India \\ Email: boramma@rediffmail.com
}

Received: 22 Jan 2020, Revised and Accepted: 15 Mar 2020

\begin{abstract}
Objective: In the present study, emphasis has been made to assay the antifungal activity of some angiospermic epiphytes like Cuscuta reflexa, Viscum orientale, Cymbidium bicolor, Bulbophyllum propinquum, Hoya ovalifolia and Dendrophthoe falcata.

Methods: The antifungal activity due to epiphytes extracts was expressed in term of reduction in dry biomass of fungi based on the relationship of ergosterol content and electrolyte leakage in fungal pathogens viz., Colletotrichum dematium, Drechslera oryzae, Fusarium oxysporum and Fusarium solani treated with epiphytes extract.
\end{abstract}

Results: Treated fungi showed increased in ergostesrol content and increased electrolyte leakage confirmed the pathetic situation of fungi; hence there was fungistatic effect, which was dose-dependent.

Conclusion: The angiospermic epiphytes of selected species chosen for the study could be serves an alternative eco-friendly source to synthetic fungicides.

Keywords: Angiospermic epiphytes, Antifungal activity, Ergosterol, Electrolyte leakage, Pathogenic fungi

(C) 2020 The Authors. Published by Innovare Academic Sciences Pvt Ltd. This is an open access article under the CC BY license (http://creativecommons.org/licenses/by/4.0/) DOI: http://dx.doi.org/10.22159/ijcpr.2020v12i3.38317. Journal homepage: https://innovareacademics.in/journals/index.php/ijcpr

\section{INTRODUCTION}

Fungi are heterotrophs growing on various substrates, draw nutrients by secreting a variety of enzymes on to the host tissues. Plant pathogenic fungi are known to release digestive enzymes like $\alpha$ amylase, protease, linginase, cellulose and cetalase during their spore germination, which in turn useful for the dissolution of the host cell wall, thus, facilitate the further establishment of mycelium in to the host tissues. In turn draw the nutrients from the host tissue. Due to the infectivity of pathogenic fungi, the plant host tissue succumbed to diseases which may result in the weakening of tissue, ultimately leads to the death of the plants at varied level of the growth stages. Due to host-pathogen interaction, there are possibilities of weakening up of the pathogenic fungal species depending up on the type of concentrating defense enzyme released from the host, which known to trigger/elicits their synthesis and accumulation in the various plant parts locally or systemically. During these interactions fungi may become week due to biological stress, leads to the loss of nutrients like amino acids, sugar, generally in the form of charged ions. As the result of loss of cell membrane integrity, the fungal cell may lose large quantity of electrolytes, become weakened, ultimately lose their vigor and die eventually or become unable to establish in to the host tissue, which a series of molecular change occur in the host cells.

Counteract with the pathogenic activity of fungi considering these aspects in the present study, emphasis has been made to relate the ergosterol content and the electrolyte leakage from the pathogenic fungi which are under treatment with epiphytes extract chosen to mitigate the fungal growth. Apart from this efforts have been made to estimate the ergosterol content in fungi treated with epiphytes extracts.

\section{MATERIALS AND METHODS}

\section{Collection of plant materials}

Leaves of angiospermic epiphytes viz., Cuscuta reflexa Roxb., Viscum orientale Wild, Cymbidium bicolor (L.) Sw., Bulbophyllum propinquum Kraenzl., Hoya ovalifolia Wild and Arnott. and Dendrophthoe falcata (L. f.) Ettingsh., were collected from different locations in and around Mysore district of Karnataka state in India and were washed with running tap water, cut into pieces and dried under shade at room temperature $\left(28 \pm 2{ }^{\circ} \mathrm{C}\right)$. The dried plant's leaves were powdered using mechanical grinder and stored in brown bottles till further use.

\section{Extraction of plant sample}

$50 \mathrm{~g}$ of powdered plant materials extracted with $70 \%$ methanol and distilled water using soxhlet extractor, separately, maintained at 65 ${ }^{\circ} \mathrm{C}$ for $72 \mathrm{~h}$. The extracted solvent was filtered using Whatman No.1 filter paper and dried. The residue of each sample was stored in the clean bottles in the refrigerator until further use.

\section{Preparation of samples for antifungal assay}

For the purpose of evaluating the antifungal activity of the selected epiphytes extracts, in vitro, the fungal cultures were grown on Potato Dextrose Broth and having pH 6.8. $150 \mathrm{ml}$ of PDB was added to a series of $250 \mathrm{ml}$ conical flasks. Such flasks were separately added with $10 \mathrm{ml}$ of 10,50 and $100 \%$ methanolic epiphyte extracts. Then, these flasks were plugged with non-absorbent cotton and sterilized in an autoclave. The sterilized flasks were further cooled and transferred to laminar hood cabinet. These flasks were individually added with culture discs (5 mm dia) target fungi, Colletotrichum dematium, Drechslera oryzae, Fusarium oxysporum and Fusarium solani individually and maintained separately.

The inoculated flasks were incubated under standard conditions of $12 / 12$ light and darkness at $22 \pm 2{ }^{\circ} \mathrm{C}$ for a period of $15 \mathrm{~d}$. Further, on $15^{\text {th }}$ day, the mycelial mats of fungi were separated from their culture filtrate by passing through pre-weighed filter paper cones. The mycelial mat of each fungus was blotted to remove water and dried for overnight at $60 \pm 2{ }^{\circ} \mathrm{C}$ overnight. For every sample PDB not amended with epiphytes extracts added with fungi and incubated similarly were considered as corresponding control.

\section{Estimation of dry biomass of fungi}

The filter paper cones having dry mycelial mat were cooled for half an hour in a desiccator containing anhydrous $\mathrm{CaCl}_{2}$ and were individually weighed using an electronic balance. The data were recorded in comparison with control and were tabulated correspondingly. The percent reduction in the fungal biomass confined to growth inhibition was calculated based on the following formula: 
Fungal (\%) Inhibition $=[(\mathrm{C}-\mathrm{T}) / \mathrm{C}] \times 100$

where; C: Fungal biomass in control, T: Fungal biomass in treatment

\section{Ergosterol content in fungi}

A modified method was used to determine the ergosterol content in the dry fungal biomass [1], consisting of $0.2 \mathrm{~g}$ of the samples with $10 \mathrm{ml}$ of methanol agitated in shaker (Tecnal, TE-141, Erechim, Brasil) at $200 \mathrm{rpm}$ for $30 \mathrm{~min}$ and this procedure was repeated thrice per sample. The methanol extract was centrifuged at $3200 \mathrm{~g}$ at $20^{\circ} \mathrm{C}$ for 10 $\min$. Then, it was refluxed for $30 \mathrm{~min}$ and cooled at $4{ }^{\circ} \mathrm{C}$. The refluxed sample was submitted to partitions with $20 \mathrm{ml}$ hexane. The hexane fraction was concentrated in a rotatory evaporator at $60{ }^{\circ} \mathrm{C}$. The residue was dissolved with $10 \mathrm{ml}$ methanol and \% transmittance was determined at $283 \mathrm{~nm}$. The ergosterol content was estimated using a calibration curve developed with standard ergosterol.

\section{Electrolyte leakage studies in fungi}

Culture mat of each fungus was further used for soaking in $50 \mathrm{ml}$ of deionized water separately in a series of $100 \mathrm{ml}$ cleaned conical beakers for a period of $18 \mathrm{~h}$ at $20 \pm 2{ }^{\circ} \mathrm{C}$. In each case, cultures obtained on PDB not amended with epiphytes extracts were considered. Then the fungal mat was further filtered using filter paper. The filtrate was used to assess the specific conductivity using a digital conductivity meter (Eauiptronics, Model No. EQ664A). For this purpose, digital conductivity meter was standardized using $0.1 \mathrm{~N}$ KCL solution and used to take reading by dipping the glass electrolyte in to the filtrate. After every reading, the electrode was washed in deionzed water and wiped with sterilized blotters. For each sample two replicates were used and the mean values were recorded in term of mmol hos/g of fungal mat. Similarly, the was recorded with respect to control samples.

The data were recorded and tabulated for comparison with that of control, as well as among different samples.

\section{RESULTS AND DISCUSSION}

Antifungal activity of methanol extracts of selected angiospermic epiphytes was carried out based on dry biomass. A different concentration of extracts was used to estimate the efficiency of promising extract, which was revealed in table 1 (table 1). Differences of reduction in fungal mat biomass indicated reduced growth, which is turn depended upon the species of angiospermic epiphytes.

Table 1: Evaluation of dry biomass of plant-pathogen fungi due to epiphytes extract

\begin{tabular}{|c|c|c|c|c|c|}
\hline \multirow{2}{*}{$\begin{array}{l}\text { Angiospermic } \\
\text { epiphyte }\end{array}$} & \multirow{2}{*}{$\begin{array}{l}\text { Concentration of } \\
\text { epiphytes extract (\%) }\end{array}$} & \multicolumn{4}{|c|}{ Inhibition of fungi due to epiphytes extract treatment \% (data based on dry biomass)* } \\
\hline & & Colletotrichum dematium & Drechslera oryzae & Fusarium saloni & Fusarium oxysporum \\
\hline \multirow[t]{3}{*}{ Cuscuta reflexa } & 10 & $7.9 \pm 0.24$ & $18.32 \pm 0.312$ & $10.4 \pm 0.241$ & $6.4 \pm 0.38$ \\
\hline & 50 & $13.8 \pm 0.54$ & $24.4 \pm 0.51$ & $16.2 \pm 0.25$ & $12.2 \pm 0.45$ \\
\hline & 100 & $20.4 \pm 0.32$ & $29.6 \pm 0.124$ & $20.3 \pm 0.54$ & $19.14 \pm 0.54$ \\
\hline \multirow{3}{*}{ Viscum oreintale } & 10 & $9.4 \pm 0.45$ & $10.6 \pm 0.61$ & $7.32 \pm 0.23$ & $9.3 \pm 0.54$ \\
\hline & 50 & $14.3 \pm 0.63$ & $15.32 \pm 0.42$ & $10.8 \pm 0.14$ & $15.3 \pm 0.19$ \\
\hline & 100 & $20.5 \pm 0.521$ & $20.6 \pm 0.45$ & $15.23 \pm 0.19$ & $20 \pm 0.28$ \\
\hline \multirow[t]{3}{*}{ Hoya ovalifolia } & 10 & $4.9 \pm 0.57$ & $4.89 \pm 0.32$ & $5.35 \pm 0.14$ & $4.8 \pm 0.24$ \\
\hline & 50 & $8.5 \pm 0.63$ & $8.41 \pm 0.14$ & $8.42 \pm 0.56$ & $9.4 \pm 0.32$ \\
\hline & 100 & $12.23 \pm 0.45$ & $12.10 \pm 0.84$ & $12.15 \pm 0.45$ & $12.13 \pm 0.82$ \\
\hline Bulbophyllum & 10 & $7.9 \pm 0.21$ & $10.5 \pm 0.21$ & $11.4 \pm 0.52$ & $16.3 \pm 0.91$ \\
\hline \multirow[t]{2}{*}{ propinquum } & 50 & $12 \pm 0.81$ & $16.21 \pm 0.412$ & $17.32 \pm 0.23$ & $22.1 \pm 0.82$ \\
\hline & 10 & $15.45 \pm 0.65$ & $20.3 \pm 0.51$ & $21.5 \pm 0.42$ & $30 \pm 0.74$ \\
\hline Cymbidium & 10 & $8.3 \pm 0.56$ & $9.8 \pm 0.45$ & $9.8 \pm 0.74$ & $8.7 \pm 0.25$ \\
\hline \multirow[t]{2}{*}{ bicolor } & 50 & $12.7 \pm 0.165$ & $15 \pm 0.42$ & $15.4 \pm 0.25$ & $14.4 \pm 0.64$ \\
\hline & 100 & $15.46 \pm 0.32$ & $20 \pm 0.74$ & $20.5 \pm 0.43$ & $20.7 \pm 0.29$ \\
\hline Dendrophthoe & 10 & $10.5 \pm 0.12$ & $19.3 \pm 0.12$ & $8.9 \pm 0.42$ & $9.2 \pm 0.71$ \\
\hline falcate (L. f.) & 50 & $18.16 \pm 0.25$ & $25.12 \pm 0.27$ & $15.1 \pm 0.81$ & $13.9 \pm 0.44$ \\
\hline Ettingsh & 100 & $23.05 \pm 0.14$ & $30.6 \pm 0.46$ & $20.3 \pm 0.26$ & $20.6 \pm 0.21$ \\
\hline
\end{tabular}

*Data represents mean value of triplicate of dry myeclial mat $\pm \mathrm{SE}, \mathrm{SE}=$ standard error

In the present investigation, ergosterol assessment as a measure of fungal growth showed antifungal activity against all tested species of fungi. The results indicated in fig. 1 revealed the ergosterol content in fungi subjected to epiphytes extract treatment (fig. 1).

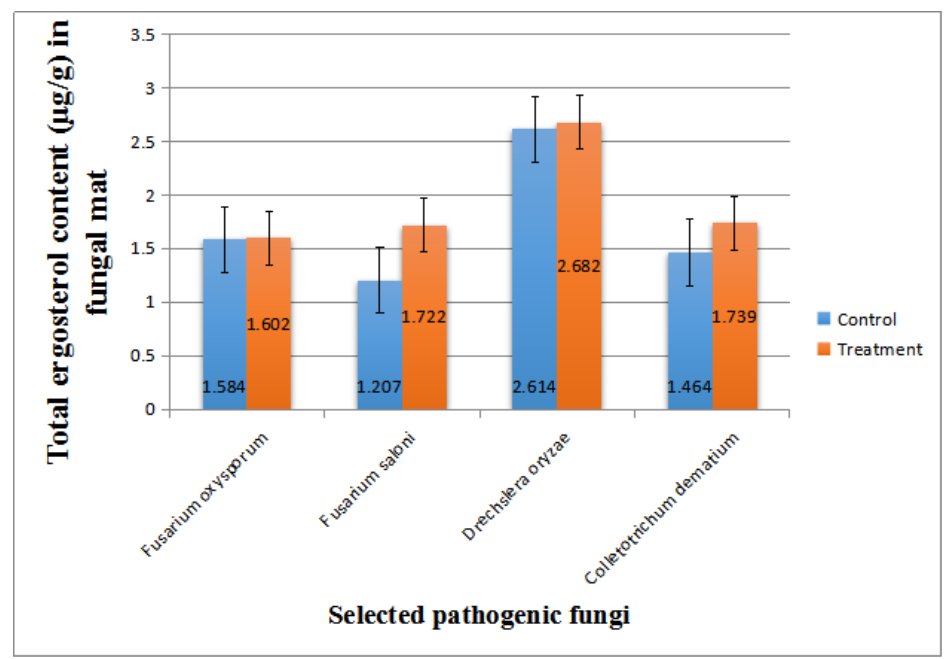

Fig. 1: Effect of epiphytes extract on the ergestrol content in plant pathogenic fungi 
Data in fig. 1 showed that there was an increase in ergosterol content in fungi, which indicated the reduction in the loss of membrane integrity of cells in target pathogenic fungi. The ergosterol content was found affected by the plant extracts compared to the control (culture without plant extract). These findings indicated the possibility of loss of cell membrane integrity leads to the inhibition of the fungi, thus exhibited the antifungal activity.

Reports available with respect to ergosterol has been used in many studies to quantify fungal biomass [2-7]. It has also been employed to quantify biomass in several studies of soil fungi, mycorrhizae [3-5] and has been used to determine biomass associated with decaying leaves in freshwaters [2, 6-8]. In parallel to this, on 1995 the good correlations between mycelial dry weight and ergosterol content for some species of ectomycorrhizal fungi found by Sung et al.

Electrolyte leakage is ubiquitous among different species and can be triggered by all major stress factors. The data with respect to the effect of epiphytes extracts on electrolyte leakage in pathogenic fungi are summarized in table 3 (table 3 ). The data recorded indicate the varied level of electrolyte leakage in different treatments. In Drechslera oryzae highest level of leakage was observed in contrast to Fusarium solani with small amount of leakage in comparison to the corresponding control.

Table 2: Role of epiphytes extract on the electrolyte leakage in plant pathogenic fungi

\begin{tabular}{lll}
\hline Selected plant pathogenic fungi & Electrolyte leakage in fungi due to epiphyte extract treatment (mMhos/g culutr mat) & treatment \\
\cline { 2 - 3 } & Control & $163.2 \pm 0.42$ \\
\hline Fusarium oxysporum & $82.6 \pm 0.34$ & $101.4 \pm 0.81$ \\
Fusarium solani & $50.4 \pm 0.74$ & $193.1 \pm 0.22$ \\
Drechslera oryzae & $67.3 \pm 0.15$ & $150.6 \pm 0.52$ \\
Colletotrichum dematium & $70.1 \pm 0.74$ & \\
\hline
\end{tabular}

Data based on the average of triplicates. \pm SE, SE = Standard Error

Electrolyte leakage was observed in almost all the samples instantaneously due to a stress factor (epiphytes extract) and lasts from a few minutes to $\mathrm{h}$. It is mainly caused by the efflux of $\mathrm{K}+$ that move to balance the efflux of positively charged potassium ions in the cell $[10,11]$. In a similar manner, the ion channel-mediated $\mathrm{K}+$ efflux can lead to K+loss that trigger cell death [12-14]. Hypothetically, this reaction can also be involved in metabolic adjustment, which is essential for adoption. The results of these investigation indicated that the relationship between growth and ergoesterol in the selected fungi, which ultimately showed inhibition of fungal biomass and increased of ergosterol content in treated samples. Similarly, the disturbance in the membrane integrity lead to increased the leakage of electrolyte.

\section{CONCLUSION}

The present fundings suggest that the imparts the effectiveness of the methanolic extract constituents as a novel source of antifungal natural bioactive compounds in the angiospermic epiphytes of selected species chosen for the study. Those could be used as fungicides, thus serves an alternative eco-friendly source to synthetic fungicides, play a role in the management of the crop plants pathogenic fungi in sustainable agriculture.

\section{ACKNOWLEDGMENT}

Authors are highly thankful to the University of Mysore, Mysuru for providing facilities to perform the experiments using angiospermic epiphytes. First author is highly thankful to the Institute of Excellence and DOS in Chemistry for providing facilities to conduct experiments in their laboratories.

\section{FUNDING}

Nil

\section{AUTHORS CONTRIBUTIONS}

All the authors have contributed equally.

\section{CONFLICT OF INTERESTS}

The authors declare that they have no conflict of interest

\section{REFERENCES}

1. Gutarowska B, Zakowska Z. Mathematical models of mycelium growth and ergosterol synthesis in stationary mould culture. Lett Appl Microl 2009;5:605-10.
2. Cook N. The perception of large-scale tonal closure. Mus Perce: An Int J 1987;2:197-205.

3. West AW, Grant WD, Sparling GP. Use of ergosterol, diaminopimelic acid and glucosamine contents of soils to monitor changes in microbial populations. Soi Bio Bioch 1987;5:607-12.

4. Lumsden RD, Carter JP, Whipps JM, Lynch JM. Comparison of biomass and viable propagule measurements in the antagonism of Trichoderma harzianum against Pythium ultimum. Soi Biol Bioch 1990;2:187-94.

5. Martin F, Delaruelle C, Hilbert JL. An improved ergosterol assay to estimate fungal biomass in ectomycorrhizas. Mycol Res 1990;8:1059-64.

6. Gessner MO, Schwoerbel J. Fungal biomass associated with decaying leaf litter in a stream. Oecol 1991;4:602-3.

7. Gessner MO, Chauvet E. Ergosterol-to-biomass conversion factors for aquatic hyphomycetes. Appl Environ Microl 1993;2:502-7.

8. Suberkropp K, Gessner MO, Chauvet E. Comparison of ATP and ergosterol as indicators of fungal biomass associated with decomposing leaves in streams. Appl Environ Microl 1993;10:3367-72.

9. Sung SJS, White LM, Marx DH, Otrosina WJ. Seasonal ectomycorrhizal fungal biomass development on loblolly pine (Pinus taeda L.) seedlings. Mycology 1995;6:439-47.

10. Palta JP, Levitt J, Stadelmann EJ. Freezing injury in onion bulb cells: I. Evaluation of the conductivity method and analysis of ion and sugar efflux from injured cells. Plant Physiol 1977;3:393-7.

11. Bajji M, Kinet JM, Lutts $S$. The use of the electrolyte leakage method for assessing cell membrane stability as a water stress tolerance test in durum wheat. Plant Growth Regul 2002;1:61-70.

12. Demidchik V, Cuin TA, Svistunenko D, Smith SJ, Miller AJ, Shabala $\mathrm{S}$, et al. Arabidopsis root $\mathrm{K}+$-efflux conductance activated by hydroxyl radicals: single-channel properties, genetic basis and involvement in stress-induced cell death. J Cell Sci 2010;9:1468-79.

13. Zepeda Jazo I, Velarde Buendia AM, Enriquez Figueroa R, Bose J, Shabala S, Muniz Murguia J, et al. Polyamines interact with hydroxyl radicals in activating Ca2+and $\mathrm{K}+$ transport across the root epidermal plasma membranes. Plant Physiol 2011;4:2167-80.

14. Demidchik V, Straltsova D, Medvedev SS, Pozhvanov GA, Sokolik A, Yurin V. Stress-induced electrolyte leakage: the role of $\mathrm{K}+$ permeable channels and involvement in programmed cell death and metabolic adjustment. J Exp Bot 2014;5:1259-70. 